\title{
SELECT BIBLIOGRAPHY AND RESOURCES
}

\section{BOOKS}

Aaron, Michelle, Spectatorship: The Power of Looking On (London: Wallflower Press, 2007).

Aldgate, Anthony and Richards, Jeffrey, Britain Can Take It: The British Cinema in the Second World War (Edinburgh: Edinburgh University Press, 1994).

Aldgate, Anthony and Robertson, James C., Censorship in Theatre and Cinema (Edinburgh, Edinburgh University Press, 2005).

Allen, Robert C. and Gomery, Douglas, Film History: Theory and Practice (Boston, MA: McGraw-Hill, 1993).

Ashby, Justine and Higson, Andrew (eds.), British Cinema, Past and Present (London: Routledge, 2000).

Barber, Sarah and Penniston-Bird, Corinna M. (eds.), History Beyond the Text: A Student's Guide to Approaching Alternative Sources (Abingdon: Routledge, 2009).

Barber, Sian, Censoring the 1970s: The BBFC and the Decade that Taste Forgot (Newcastle: Cambridge Scholars Publishing, 2011).

Barber, Sian, The British Film Industry in the 1970s: Capital, Culture and Creativity (Basingstoke: Palgrave Macmillan, 2013).

Barker, Martin (ed.), The Video Nasties: Freedom and Censorship in the Media (London: Pluto Press, 1984).

Barr, Charles, Ealing Studios (Moffat: Cameron \& Hollis, 1998).

Barta, Tony (ed.), Screening the Past: Film and the Representation of History (Westport, CT: Praeger, 1998).

Bazin, André, What is Cinema?, essays selected and trans. Hugh Gray, 2 vols (Berkeley, CA, and London: University of California Press, 2005).

Bell, Melanie, Femininity in the Frame: Women and 1950 s British Popular Cinema (London: I.B. Tauris, 2009). 
Bloch, Marc, The Historian's Craft, trans. Peter Putnam, preface by Peter

Burke (Manchester: Manchester University Press, 1992).

Bordwell, David, On the History of Film Style (Cambridge, MA, and London:

Harvard University Press, 1997).

Bordwell, David and Thompson, Kristin, Film Art: An Introduction (Boston,

MA, and London: McGraw-Hill, 2004).

Bordwell, David and Thompson, Kristin, Film History: An Introduction, 3rd edition (New York: McGraw-Hill Higher Education, 2010).

Braudy, Leo, Cohen, Marshall and Mast, Gerald (eds.), Film Theory and

Criticism: Introductory Readings, 4th edition (New York and Oxford:

Oxford University Press, 1992).

Burgess, Jean and Green, Joshua, YouTube, Digital Media and Society series (Cambrdige: Polity Press, 2009).

Burke, Peter, Varieties of Cultural History (Cambridge: Polity Press, 1997).

Burrows, Elaine et al. (eds.), The British Cinema Source Book: BFI Archive

Viewing Copies and Library Materials (London: BFI Publishing, 1995).

Chambers, Ciara, Ireland in the Newsreels (Dublin: Irish Academic Press, 2012).

Chapman, James, The British at War: Cinema, State and Propaganda, 1939-45

(London: I.B Tauris, 1998).

Chapman, James, Past and Present: National Identity and the British Historical

Film (London: I.B. Tauris, 2005).

Chapman, James, Film and History (Basingstoke: Palgrave Macmillan, 2013).

Chapman, James, Glancy, Mark and Harper, Sue, The New Film History:

Sources, Methods, Approaches (New York and Basingstoke: Palgrave

Macmillan, 2007).

Chiball, Steve and Murphy, Robert (eds.), British Crime Cinema (London: Routledge, 1999).

Colman, Felicity (ed.), Film, Theory and Philosophy: The Key Thinkers (Durham, NC: Acumen, 2009).

Cook, Pam, Fashioning the Nation: Costume and Identity in British Cinema (London: BFI Publishing. 1996).

Cook, Pam and Bernink, Mieke, The Cinema Book, 2nd edition (London: BFI Publishing, 1999).

Corrigan, Timothy J., A Short Guide to Writing About Film (New York and London: Pearson Longman, 2007).

Corrigan, Timothy and White, Patricia, The Film Experience: An Introduction

(Boston: Bedford/St Martin's, 2009).

Creeber, Glen, Tele-visions: An Introduction to Studying Television (London: BFI

Publishing, 2006). 
Dickinson, Margaret and Street, Sarah, Cinema and State: The Film Industry and the British Government 1927-1984 (London: BFI Publishing, 1985).

Drazin, Charles, The Finest Years: British Cinema of the 1940s (London: I.B. Tauris, 2007).

Dyer, Richard, The Matter of Images: Essays in Representation (London: Routledge, 1993).

Ede, Laurie N., British Film Design: A History (London: I.B. Tauris, 2010).

Egan, Kate, Trash or Treasure? Censorship and the Changing Meaning of the Video Nasties (Manchester: Manchester University Press, 2007).

Ellis, Jack C., History of Film (Boston, MA, and London: Allyn and Bacon, 1995).

Flanagan, Martin, Bakhtin and the Movies: New Ways of Understanding Hollywood Film (Basingstoke: Palgrave Macmillan, 2009).

Foster, Janet and Sheppard, Julia (eds.), British Archives: A Guide to Archive Resources in the United Kingdom (Basingstoke: Palgrave, 2002).

Gerarghty, Christine, British Cinema in the Fifties: Gender, Genre and the 'New Look' (London: Routledge, 2000).

Gibbs, John, Mise-en-Scene: Film Style and Interpretation (London: Wallflower Press, 2001).

Gifford, Denis, British Film Catalogue: Fiction Film 1895-1994, Volume 1, 3rd edition (London: Fitzroy Dearborn, 2001).

Gillham, Bill, The Research Interview (London: Continuum, 2000).

Glancy, Mark H., When Hollywood Loved Britain: The Hollywood British Film, 1939-45 (Manchester: Manchester University Press, 1999).

Gocsik, Karen and Barsam, Richard, Writing About Movies (New York: Norton, 2007).

Grainge, Paul, Jancovich, Mark and Monteith, Sharon, Film Histories: An Introduction and Reader (Edinburgh: Edinburgh University Press, 2007).

Green, Anna and Troup, Kathleen, The Houses of History: A Critical Reader in Twentieth-Century History and Theory (Manchester: Manchester University Press, 1999).

Grenville, J.A.S., Film as History (Birmingham: University of Birmingham Press, 1971).

Hanson, Stuart, From Silent Screen to Multi-Screen: A History of Cinema Exhibition in Britain since 1896 (Manchester: Manchester University Press, 2007).

Harper, Sue, Picturing the Past: The Rise and Fall of the British Costume Film (London: BFI Publishing, 1994).

Harper, Sue, Women in British Cinema: Mad, Bad and Dangerous to Know (London: Continuum, 2000). 
Harper, Sue and Porter, Vincent, British Cinema of the 1950s: The Decline of Deference (Oxford: Oxford University Press 2003).

Harper, Sue and Smith, Justin (eds.), British Film Culture in the 1970s: The Boundaries of Pleasure (Edinburgh: Edinburgh University Press, 2011).

Haskell, Molly, From Reverence to Rape: The Treatment of Women in the Movies, 2nd edition (Chicago: University of Chicago Press, 1987).

Hibbin, Sally and Hibbin, Nina, What a Carry On: Official Carry On Movie Book (London: Hamlyn 1988).

Higson, Andrew, Film England: Culturally English Filmmaking Since the 1990s (London: I.B. Tauris, 2011).

Hill, John, Sex, Class and Realism: British Cinema 1956-1963 (London: BFI Publishing, 1986).

Hill, John, British Cinema in the 1980s: Issues and Themes (Oxford: Clarendon Press, 1999).

Holmes, Su, British TV and Film Culture of the 1950s: Coming to a TV Near You! (Bristol: Intellect, 2005).

Hughes-Warrington, Marnie (ed.), History on Film Reader (Abingdon: Routledge, 2009).

Hughes-Warrington, Marnie, History Goes to the Movies: Studying History on Film (Abingdon: Routledge, 2007).

Hunt, Leon, British Low Culture: From Safari Suits to Sexploitation (London: Routledge. 1998).

Hutchings, Peter, Hammer and Beyond: The British Horror Film (Manchester: Manchester University Press, 1993).

Huxley, Aldous, The Devils of Loudun (London: Chatto \& Windus, 1952). Huzinga, Johan, Men and Ideas: History, the Middle Ages and Renaissance, trans. James S. Holmes and Hans van Marle (London: Eyre and Spottiswoode, 1960).

Jancovich, Mark, Faire, Lucy and Stubbings, Sarah, The Place of the Audience: Cultural Geographies of Film Consumption (London: BFI Publishing, 2003). Jordanova, Ludmilla, History in Practice (London: Hodder Headline, 2000). Kracauer, Siegfried, From Caligari to Hitler: A Psychological Study of the German Film (Princeton, NJ, and Oxford: Princeton University Press, 2004).

Kuhn, Annette, Women's Pictures: Feminism and Cinema (London: Routledge and Kegan Paul, 1982).

Kuhn, Annette, Cinema, Censorship and Sexuality, 1909-25 (London: Routledge, 1988).

Lamberti, Ed (ed.), Behind the Scenes at the BBFC: Film Classification from the Silver Screen to the Digital Age (London: BFI Publishing/Palgrave Macmillian, 2012). 
Landy, Marcia (ed.), The Historical Film: History and Memory in Media (New Brunswick, NJ: Rutgers University Press, 2000).

Leach, Jim, British Film (Cambridge: Cambridge University Press, 2004).

Low, Rachael The History of British Film, 7 vols (London and New York: Routledge, 1997; originally published Allen \& Unwin, 1948).

Machin, David and Mayr, Andrea, How to Do Critical Discourse Analysis: A Multimodal Introduction (London: Sage, 2012).

McFarlane, Brian, The Encyclopaedia of British Film, 3rd edition (London: Methuen, 2008).

McKernan, Luke (ed.), Yesterday's News: The British Cinema Newsreel Reader (London: BUFVC Press, 2002).

Medhurst, Andy, A National Joke: Popular Comedy and English Cultural Identities (Abingdon: Routledge, 2007).

Metz, Christian, Film Language: A Semiotics of the Cinema, trans. Michael Taylor (Chicago: University of Chicago Press, 1991; originally published Oxford: Oxford University Press, 1974).

Monaco, James, How to Read a Film: The World of Movies, Media and Multimedia: Language, History, Theory (New York and Oxford: Oxford University Press, 2000).

Monk, Claire and Sargeant, Amy (eds.), British Historical Cinema (London: Routledge, 2002).

Mulvey, Laura, Visual and Other Pleasures (Basingstoke: Macmillan, 1989).

Murphy, Robert, Realism and Tinsel: Cinema and Society in Britain 1939-48, 2nd edition (London: Routledge, 1992).

Murphy, Robert, British Cinema of the 90s (London: BFI Publishing, 2000).

Murphy, Robert, British Cinema and the Second World War (London: Continuum, 2000).

Murphy, Robert, The British Cinema Book, 2nd edition (London: BFI Publishing, 2001).

Murphy, Robert, Sixties British Cinema (London: BFI Publishing, 2008).

Newland, Paul (ed.), Don't Look Now: British Cinema in the 1970s (Bristol: Intellect, 2010).

Newland, Paul, British Films of the 1970s (Manchester: Manchester University Press, 2013).

Nichols, Bill, Movies and Methods: An Anthology, vols 1 and 2 (Berkeley, CA, and London: University of California Press, 1976).

Ó Dochartaigh, Niall, Internet Research Skills: How to Do your Literature Search and Find Research Information Online (Los Angeles: Sage, 2007).

Orpen, Valerie, Film Editing: The Art of the Expressive (London: Wallflower Press, 2003). 
Pears, Richard and Shields, Graham, Cite them Right: The Essential Referencing

Guide, 9th edition (Basingstoke: Palgrave Macmillan, 2013).

Pereboom, Maartin, History and Film: Moving Pictures and the Study of the Past (Upper Saddle River, NJ: Pearson, 2010).

Petley, Julian, Film and Video Censorship in Modern Britain (Edinburgh: Edinburgh University Press, 2011).

Petrie, Duncan, The British Cinematographer (London: BFI Publishing, 1996).

Powell, Danny, Studying British Cinema: The 1960s (New York: Auteur Press, 2009).

Propp, Vladimir, The Russian Folktale, ed. and trans. Sibelan Forrester, foreword by Jack Zipes (Detroit: Wayne State University Press, 2012).

Pucci, Suzanne R. and Thompson, James, Jane Austen and Co: Remaking the

Past in Contemporary Culture (Albany, NY: State University of New York Press, 2003).

Richards, Jeffrey, The Age of the Dream Palace: Cinema and Society 1930-1939 (London: Routledge and Kegan Paul, 1984).

Robertson, James C., The Hidden Cinema: British Film Censorship in Action, 1913-1975 (London: Routledge, 1993).

Robson, Colin, How to Do a Research Project: A Guide for Undergraduate Students (Oxford: Blackwell, 2007).

Rosenstone, Robert A., History on Film/Film on History (Harlow: Pearson, 2012).

Rudestam, Kjell and Newton, Rae, Surviving your Dissertation: A Comprehensive Guide to Content and Process, 3rd edition (London: Sage, 2007).

Sargeant, Amy, British Cinema: A Critical History (London: BFI Publishing, 2005).

Sedgwick, John, Popular Filmgoing in 1930s Britain: A Choice of Pleasures (Exeter: University of Exeter Press, 2000).

Sedgwick, John and Pokorny, Michael (eds.), An Economic History of Film (London: Routledge, 2005).

Shail, Robert (ed.), Seventies British Cinema (London: BFI Publishing/ Palgrave Macmillan, 2008).

Smith, Justin, Withnail and Us: Cult Films and Film Cults in British Cinema (London: I.B. Tauris, 2010).

Smith, Paul (ed.), Film and the Historian (Cambridge: Cambridge University Press, 1976).

Sorlin, Pierre, The Film in History: Restaging the Past (Basil Blackwell: Oxford, 1980).

Spicer, Andrew, Typical Men: Representations of Masculinity in the Popular British Culture (London: I.B. Tauris, 2001). 
Stacey, Jackie, Stargazing: Hollywood Cinema and Female Spectatorship (London: Routledge, 1994).

Stam, Robert (ed.), Film Theory: An Introduction (Malden, MA: Blackwell, 2000).

Stokes, Melvyn and Maltby, Richard (eds.), American Movie Audiences : From the Turn of the Century to the Early Sound Era (London: BFI Publishing, 1999).

Street, Sarah, British National Cinema (London: Routledge: 1997).

Street, Sarah, British Cinema in Documents (London: Routledge, 2000).

Stubbs, Jonathan, Historical Film: A Critical Introduction (London: Bloomsbury, 2013).

Thompson, Kristin, Storytelling in the New Hollywood: Understanding Classical Narrative Technique (Cambridge, MA: Harvard University Press, 1999).

Tosh, John, The Pursuit of History, 4th edition (Harlow: Pearson Education, 2006).

Trevelyan, John, What the Censor Saw (London: Michael Joseph, 1973).

Walker, Alexander, Hollywood England: The British Film Industry in the 1960s, 2nd edition (London: Harrap, 1986).

Walker, John, Once and Future Film: British Cinema in the Seventies and Eighties (London: Methuen, 1985).

Walliman, Nicholas, Your Research Project: A Step-by-step Guide for the First-time Researcher (London: Sage, 2000).

Walliman, Nicholas, Your Undergraduate Dissertation: The Essential Guide for Success (London: Sage, 2004).

Wheatley, Helen, Re-viewing Television History: Critical Issues in Television Historiography (London: I.B. Tauris, 2007).

Williams, Raymond, Culture and Society 1780-1950 (Harmondsworth: Penguin, Chatto \& Windus, 1961).

Williams, Raymond, Problems in Materialism and Culture (London: Verso/ NLB, 1980).

Wistrich, Enid, 'I Don't Mind the Sex, it's the Violence': Film Censorship Explored (London: Marion Boyars Publishers, 1978).

\section{CHAPTERS IN EDITED VOLUMES}

Hughes, William, 'The evaluation of film as evidence' in Paul Smith (ed.), Film and the Historian (Cambridge: Cambridge University Press, 1976), pp. $49-71$. 
Petley, Julian, 'Us and them' in Martin Barker and Julian Petley (eds.), Ill Effects: The Media Violence Debate, 2nd edition (London: Routledge, 2001), pp. 87-101.

Richards, Jeffrey, 'Rethinking British cinema' in Justine Ashby and Andrew Higson (eds.), British Cinema: Past and Present (Abingdon: Routledge, 2000), pp. 21-34.

Richards, Jeffrey, 'Film and TV: the moving image' in Sarah Barber and Corinna M. Penniston-Bird (eds.), History Beyond the Text: A Student's Guide to Approaching Alternative Sources (London: Routledge, 2009), pp.72-86.

Rosenstone, Robert A., 'History in images/history in words' in Marnie Hughes-Warrington (ed.), History on Film Reader (Abingdon: Routledge, 2009) pp. 30-41.

Sorlin, Pierre, 'The film in history' in Marnie Hughes-Warrington (ed.), History on Film Reader (Abingdon: Routledge, 2009), pp. 15-16.

Zemon Davis, Natalie, 'Any resemblance to persons living or dead: Film and the challenge of authenticity' in Marnie Hughes-Warrington (ed.), History on Film Reader (Abingdon: Routledge, 2009), pp. 17-29.

\section{JOURNAL ARTICLES}

James, Robert, 'Kinematograph Weekly in the 1930s: trade attitudes towards audience taste', Journal of British Cinema and Television 3:2 (2006), 229-243.

Mulvey, Laura, 'Visual pleasure and narrative cinema', Screen 16:3 (1975), 6-18.

Spicer, Andrew, 'The production line: reflections on the role of the producer in British cinema', Journal of British Cinema and Television 1:1 (November 2004), 33-50.

\section{ONLINE ARTICLES}

BBFC, 'Audiences and receptions of sexual violence in contemporary cinema', BBFC, 2 October 2007, http://bbfc.co.uk/what-classification /research (accessed 14 October 2014).

Bradby, Barbara, 'Our affair with Mila Kunis: a group ethnography of cinema-going and the "male gaze"', Participations: Journal of Audience and Perception Studies 10:1 (May 2013), www.participations.org/Volume \%2010/Issue\% 201/2\%20Bradby10.1.pdf (accessed 14 October 2014). 
Hills, Matt, 'Fiske's "textual productivity" and digital fandom: Web 2.0 democratization versus fan distinction?', Participations: Journal of Audience and Perception Studies 10:1 (May 2013), www.participations. org/Volume\%2010/Issue\%201/9\%20Hills\%2010.1.pdf (accessed 14 October 2014).

Pett, Emma, “'Hey! Hey! I've seen this one, I've seen this one. It's a classic!”: nostalgia, repeat viewing and cult performance in Back to the Future, Participations: Journal of Audience and Perception Studies 10:1 (May 2013), www.participations.org/Volume\%2010/Issue\%201/11\%20Pett\% 20 10.1.pdf (accessed 14 October 2014).

von Tunzelmann, Alex, 'The Other Boleyn Girl: Hollyoaks in fancy dress', Guardian, 7 August 2008, www.guardian.co.uk/film/2008/ aug/07/1?INTCMP=SRCH (accessed 14 October 2014).

Whitlock, Cathy, 'The grand estates and castles of period moves', Architectural Digest online, www.architecturaldigest.com/ad/set-design/2013/ period-movies-set-design-manors-castles-vanity-fair-jane-eyre-article (acessed 15 October 2014).

\section{ONLINE JOURNALS}

BFI Screenonline: www.screenonline.org.uk.

Cineaste, www.cineaste.com.

Film Studies for Free, http:/ / filmstudiesforfree.blogspot.co.uk.

Moving Image Source, www.movingimagesource.us.

Participations: Journal of Audience and Perception Studies, www.participations.org. Variety, http://variety.com.

Vertigo, www.closeupfilmcentre.com/vertigo_magazine.

\section{RESOURCES}

\section{BBC Written Archives Centre}

Peppard Road

Caversham Park

Reading

RG4 8TZ

UK

Phone: 01189486281

Email: heritage@bbc.co.uk

Web: www.bbc.co.uk/historyofthebbc/contacts/wac 


\section{British Board of Film Classification}

3 Soho Square

London

W1D 3HD

UK

Phone: 02074401570.

Web: www.bbfc.co.uk/education-resources/book-visit-bbfc-archives

\section{British Film Institute Reuben Library}

BFI Southbank

Belvedere Road

South Bank

London

SE1 8XT

UK

Web: www.bfi.org.uk/education-research/bfi-reuben-library

\section{British Library}

96 Euston Road

London

NW1 2DB

UK

Phone: 01937546060

Email: Customer-Services@bl.uk

Web: www.bl.uk

\section{British Universities Film \& Video Council}

77 Wells Street

London

W1T 3QJ

UK

Phone: 02073931500

Email: ask@bufvc.ac.uk

Web: www.bufvc.ac.uk

\section{Harry Ransom Center}

University of Texas at Austin

300 West 21st Street

Austin

Texas 78713-7219

USA 
Phone: (512) 471-8944

Web: www.hrc.utexas.edu/collections/film

\section{Imperial War Museum (London)}

Lambeth Road

London

SE1 6HZ

UK

Phone: 02074165000

Email: mail@iwm.org.uk

Web: www.iwm.org.uk

\section{The National Archives}

Kew

Richmond

Surrey

TW9 4DU

UK

Phone: 02088763444

Web: www.nationalarchives.gov.uk

\section{Margaret Herrick Library}

Fairbanks Center for Motion Picture Study

333 South La Cienega Blvd

Beverly Hills

California 90211

USA

Phone: (310) 2473020

Web: www.oscars.org/library

\section{UCLA Film and Television Archive}

UCLA Campus

Archive Research and Study Center (ARSC)

46 Powell Library

Los Angeles

California 90095

USA

Phone: (310) 2065388

Email: arsc@cinema.ucla.edu

Web: www.cinema.ucla.edu 


\section{Hollywood Campus}

1015 N. Cahuenga Blvd

Hollywood

California 90038

USA

Phone: (323) 4624921

Web: www.cinema.ucla.edu

Online archives and holdings

BECTU，www.uea.ac.uk/film-television-media/research/research-themes/ british-film-and-tv-studies/british-cinema/oral-history-project.

British Pathé, www.britishpathe.com.

EUscreen, www.euscreen.eu.

European Film Gateway, www.europeanfilmgateway.eu.

Film Archives UK, http:/ / filmarchives.org.uk.

Huntley Film Archive, www.huntleyarchives.com.

Movietone, www.movietone.com/n_Index.cfm.

Moving Image Archive, https://archive.org/details/movies. 